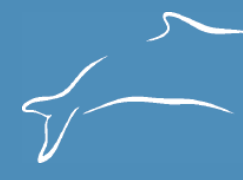

ARTICLE INFO
\begin{tabular}{|l|}
\hline Manuscript type \\
\hline Article history \\
\hline Received \\
\hline Received in revised form $\quad$ 19 Jecember 2018 \\
\hline Accepted 2019 \\
\hline Available online $\quad$ 12 June 2019 \\
\hline Responsible Editor: Carlos Olavarría \\
\hline $\begin{array}{l}\text { Citation: Cárcamo, D., Pizarro, M., Orellana, M., Pavez, G., } \\
\text { Durán, L.R. and Oliva, D. (2019) New non-breeding colonies of } \\
\text { the South American fur seal in central Chile. Is the distribution } \\
\text { in the southeastern Pacific waters extending? Latin American } \\
\text { Journal of Aquatic Mammals 14(1): 9-17. } \\
\text { https://doi.org/10.5597/lajam00249 }\end{array}$ \\
\hline
\end{tabular}

The South American fur seal (SAFS), Arctocephalus australis (Zimmermann, 1783) (Fig. 1), is a top marine predator with an estimated population of 219,000 individuals (Cárdenas-Alayza et al., 2016), which are distributed along the southwestern Atlantic and the southeastern Pacific coasts of South America. In the Atlantic Ocean, a total of 45,600 individuals have been recorded in Uruguay (Franco-Trecu et al., 2019), although another abundance estimate for the Uruguayan coast is of about 130,000 individuals (Crespo et al., 2015; Franco-Trecu, 2015; Cárdenas-Alayza et al., 2016). At least 20,000 individuals have been recorded in Argentina (Crespo et al., 2015); between 18,000-20,000 individuals have been recorded in the Malvinas/Falkland Islands (Strange, 1992) and there is an undetermined vagrant population in Brazil (Oliveira, 2013). In the Pacific Ocean the distribution is discontinuous, with a gap that extends along the coast of Chile from $29^{\circ} 02^{\prime} \mathrm{S}$ to $43^{\circ} 36^{\prime} \mathrm{S}$ (Fig. 2). The population reaches 86,000 individuals on the coasts of Chile and Peru, of which 20,900 individuals have been recorded for the Peruvian/northern Chile population ${ }^{1,2}$, while the population of southern Chile has an estimated size of 65,100 individuals (Torres et al., 2000).

Two evolutionary units have been evidenced in the SAFS, through analysis of the size and shape of the skull (morphometric and traditional geometric) (Oliveira et al.,

\footnotetext{
${ }^{1}$ Instituto del Mar del Peru (IMARPE). (2013) Anuario cientifico y tecnológico (Vol. 13). Callao, Perú. 214 pp.

${ }^{2}$ Majluf, P. (1998) Effects of the 1997/1998 El Niño on pinnipeds in Peru. In Abstracts, 8a. Reunión de Trabajo de Especialistas en Mamíferos Acuáticos de América del Sur y 2do. Congreso de la Sociedad Latinoamericana de Especialistas en Mamíferos Acuáticos (SOLAMAC), 25-29 October 1998, Olinda, PE, Brazil. 120 pp.
}

\section{New non-breeding colonies of the South American fur seal in central Chile. Is the distribution in the southeastern Pacific waters extending? Daniel Cárcamo ${ }^{\dagger, \ddagger,}$, Marlene Pizarro ${ }^{\ddagger}$, Muriel Orellana $^{\ddagger}$, Guido Pavez ${ }^{\ddagger}$, , L. René Durán ${ }^{\ddagger}$ and Doris Oliva ${ }^{\dagger, \ddagger}$ \\ ${ }^{\dagger}$ Instituto de Biología, Facultad de Ciencias, Universidad de Valparaíso. Av. Gran Bretaña 1111, Playa Ancha, Valparaíso, Chile \\ *Centro de Investigación y Gestión de Recursos Naturales (CIGREN), Facultad de Ciencias, Universidad de Valparaíso. Av. Gran Bretańa 1111, Playa Ancha, Valparaíso, Chile \\ ${ }^{\S}$ Núcleo Milenio de Salmónidos Invasores INVASAL, Universidad de Concepción, Concepción, Chile \\ *Corresponding author: daniel.carcamo@uv.cl ORCID: https://orcid.org/0000-0003-0546-8123}

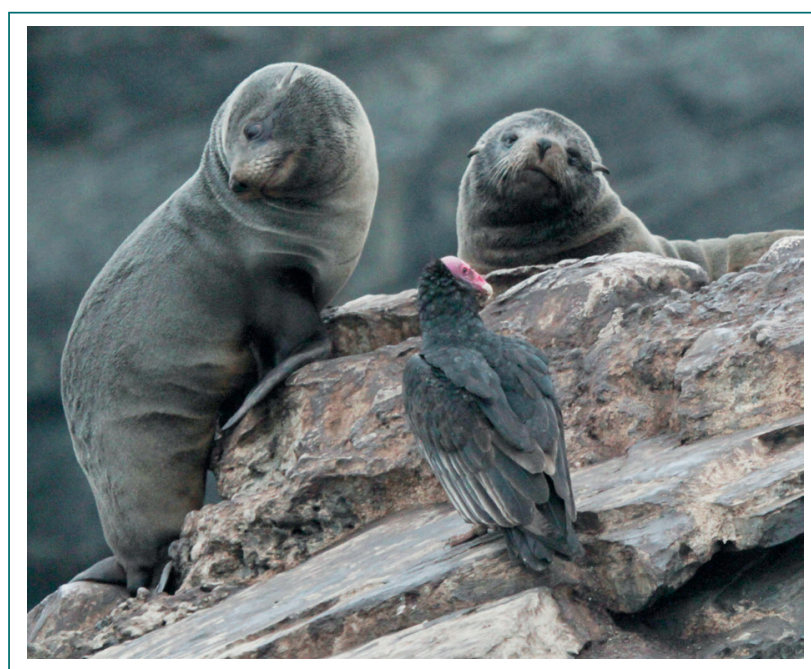

Figure 1. South American fur seal (Arctocephalus australis). Photo credit: L. René Durán.

2008). Genetic data and reproductive patterns indicate that currently the Peruvian and Uruguayan populations are reproductively isolated (Majluf, 1987; Oliveira et al., 2008; Cárdenas-Alayza, 2012; Franco-Trecu et al., 2014; Pavés et al., 2016) and that the southern Chile and Atlantic populations share several haplotypes (Crespo et al., 2015; Rodrigues et al., 2018) and synchrony in the reproductive period (Pavés et al., 2016), suggesting a connection between these populations. There is enough evidence (morphometric, genetic and from life history features) to consider the Peruvian/northern Chile and the southern Chile/Atlantic populations as different evolutionary units or even subspecies (Oliveira and Brownell, 2014). 
The ENSO event that occurred from 1997 to 1998 in northern Peru caused a high rate of SAFS pup and juvenile mortality, as well as female mortality, as a consequence of longer foraging trips ${ }^{2}$. According to Oliveira et al. (2006), the Pacific population of SAFS is well-adapted to ENSO events, but the increase in strength and frequency of events similar in magnitude to the 1997-1998 event could severely impact the local population. The SAFS Peruvian population experienced a genetic bottleneck that could be a result of synergic climatological and anthropogenic effects (Oliveira et al., 2009). Climate change and its influence on ENSO events (NCDC-NOOA, 2004; Collins et al., 2010) is a key phenomenon that would model the top predator species abundance and would explain shifts in the distribution range of marine mammals (Simmonds and Isaac, 2007).

During the eighteenth century, numerous whaling and sealing ships caught thousands of marine mammals in the Southern Hemisphere, among them the South American sea lion (SASL, Otaria byronia), the SAFS and the southern elephant seal (Mirounga leonina), obtaining fur and oil. The hunting activity continued until the beginning of the nineteenth-century. According to historical evidence, more than 400 European and American ships were dedicated to the killing of fur seals in Mocha (38 $\left.23^{\prime} S\right)$ and Santa María ( $\left.37^{\circ} 01^{\prime} S\right)$ islands, the Juan Fernández Archipelago (333' S), San Félix (26 $17^{\prime} S$ ) and San Ambrosio (26 20'S) islands off central Chile, and along the coast of southern Patagonia

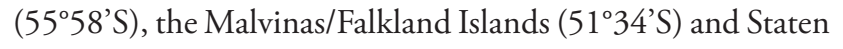
Island (5445'S) (Sielfeld et al., 1977; Torres et al., 2000). Moreover, the Diego Ramírez Islands (56³0'S), Staten Island and other neighboring islands of the Cape Horn Archipelago were considered the main hunting grounds in the southern tip of the South American continent according to other reports (Martinic, 1987). The levels of sealing during those centuries considerably reduced the populations and consequently the activity ceased in the middle of the nineteenth century (Martinic, 1987). Fur seals were driven almost to extinction along the South American coast and Antarctic Peninsula during these centuries ${ }^{3}$ (Bonner, 1982; Mayorga, 2016; 2017). This heavy hunting of SAFS is reflected today in the relatively low abundance throughout the distribution range.

The aim of this study is to show new distribution and abundance records of the SAFS in the gap of distribution, between $29^{\circ} 02$ 'S and $43^{\circ} 36^{\prime} \mathrm{S}$, as a consequence of the colonization process of animals from the Peruvian and southern Chile populations.

Aerial censuses were performed in Chile during the austral summer (17 February to $14 \mathrm{March}$ ) and winter (1 to 4 July) of 2015 , between $32^{\circ} 12^{\prime}$ S and $39^{\circ} 24^{\prime} S$. Aerial

3Ponce de León, A. (2000) Taxonomía, sistemática y sinopsis de la biología y ecología de los pinipedios de Uruguay. Sinopsis de la biología y ecología de las poblaciones de lobos finos y leones marinos de Uruguay. Pautas para su manejo y Administración. Parte I, Biología de las especies, Uruguay. Proyecto URU/92/003. censuses were also performed between $41^{\circ} 44^{\prime} \mathrm{S}$ and $44^{\circ} 55^{\prime} \mathrm{S}$ during the austral summer (13 February, 28-29 February, 15 February and 12 February of the years 2013, 2016, 2017 and 2018, respectively). The summer survey dates coincided with the post-reproductive period of the species whereas the winter survey coincided with the foraging season (Pavés and Schlatter, 2008). Both geographical areas were surveyed synoptically for a study of abundance of the SASL in the main reproductive colonies of the Southeastern Pacific Ocean. The surveys were carried out by air (Cessna 172), because the geographical areas present limited access by ground and sea. Digital photographs were taken, using CANON 7D, 40D and Rebel XT digital cameras with objectives of 70-200 F / 4 L IS, 100-400 F / 4.5-5.6 IS and 28-135 F / 3.5-5.6 IS, respectively. The CANON camera $7 \mathrm{D}$ has a GPS CANON GP-E2 that connects directly to the camera, and the georeferencing process executed by this device was recorded in the metadata of each photograph. The aerial photographs were taken at 70 to 250 masl, depending on the meteorological and topographical conditions, at 60 to $90 \mathrm{kn}$, according to Aguayo and Maturana (1973). Three independent observers counted the total of individuals and categorized them into functional age classes. Stranding records of live SAFS from the National Fishing and Aquaculture Service (SERNAPESCA) ${ }^{4}$ from 2009 to 2016 were included to complement the research sightings within the gap. We followed previous considerations to define the type of colony as breeding (presence of newborn pups) or non-breeding (absence of newborn pups) (Sepúlveda et al., 2001; 2011; Grandi et al., 2008); whereas a haulout site was defined by a single individual seen resting at a location. Based on secondary characteristics indicated by Bininda-Emonds and Gittleman (2000) and Lindenfors et al. (2002), individuals in the colonies and haul-out sites were categorized by three independent trained observers as adult males, adult females and juveniles. When it was not possible to classify an individual, it was categorized as indeterminate. All the data were combined to create distribution maps of the total sightings using ArcGis $10.2^{\odot}$.

Our results showed two non-breeding colonies and 12 haul-out sites along the gap of distribution in the Pacific coast of Chile. The two non-breeding colonies, Islote del Trabajo $\left(38^{\circ} 25^{\prime}\right.$ S) and Islote Quechol (38 $\left.26^{\prime} S\right)$, were found in adjacent islets of the Mocha Island National Reserve (38 $22^{\prime} \mathrm{S}$ ) in the Biobío Region, central Chile (Fig. 2). These new nonbreeding colonies (Figs. 2, 3) consisted of 43 individuals during the austral winter of 2015, of which $27(2 \pm 0$ adult males, $23 \pm 1$ adult females and $2 \pm 1$ juveniles) were recorded in Islote del Trabajo and $16(3 \pm 0$ adult males and $13 \pm 0$ adult females) in Islote Quechol.

During the 2016 summer survey, an indeterminate sea lion was observed in the Punta Chaiguaco haul-out site

${ }^{4}$ Stranding records from SERNAPESCA include stranded (dead) and sightings of live marine mammals. Obtained from SIAC-SERNAPESCA on 06 February 2017. 


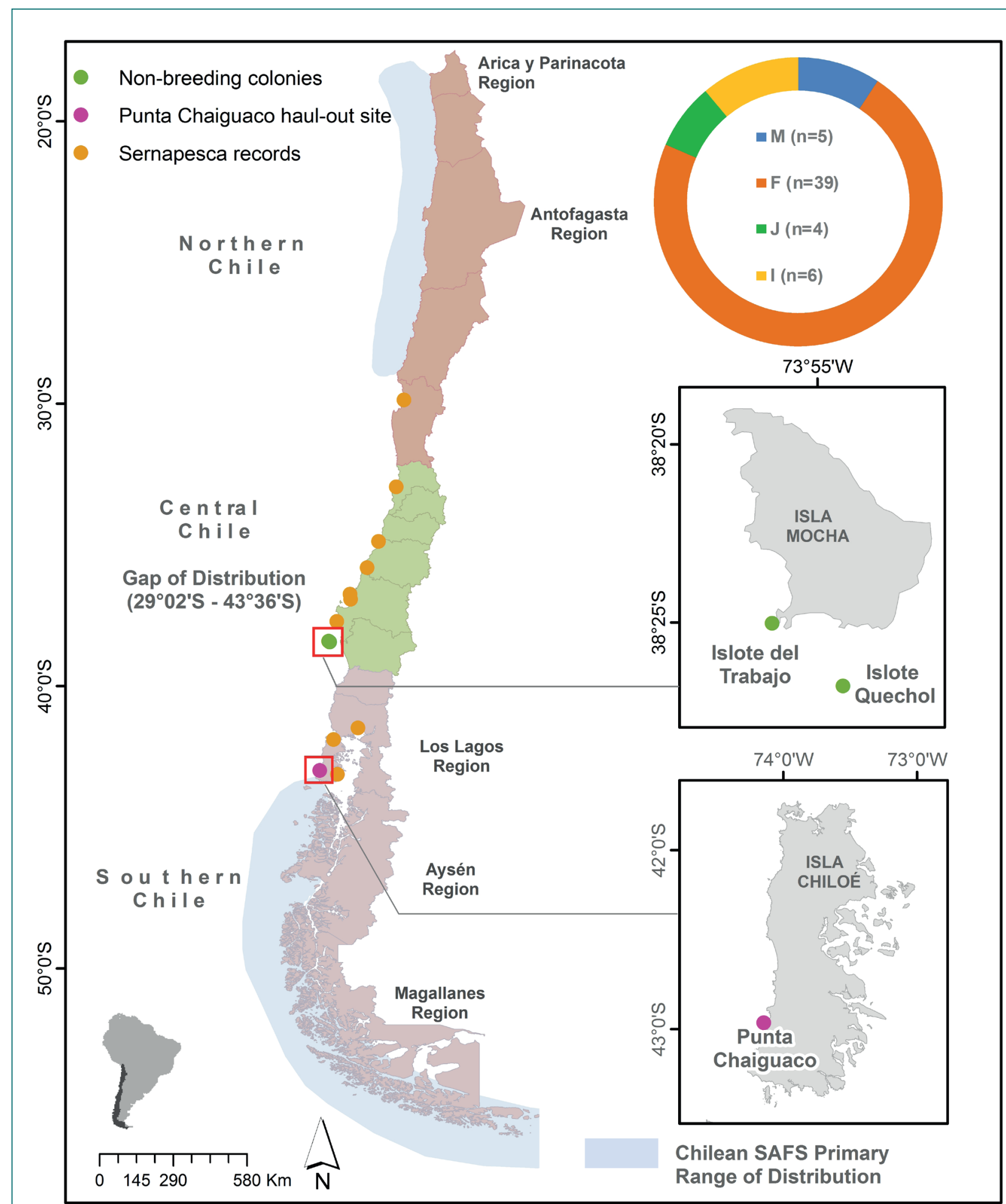

Figure 2. Sightings of South American fur seal (Arctocephalus australis) between 2009 and 2018 from aerial censuses and SERNAPESCA stranding records inside the gap of distribution in the southeast Pacific coast of Chile. Age classes: $\mathrm{M}=$ Adult Males, F= Adult Females, J= Juveniles, I= Indeterminates).

(4259'S) (Fig. 2) among a group of SASL juvenile females in the Chiloé Archipelago, southern Chile. This sea lion appeared to be morphologically different from a SASL or a SAFS. Potentially, the specimen is a hybrid sea lion (SASL and SAFS), characterized by a different kind of fur, prominent flipper and larger external ear in comparison to SASL individuals that inhabit this rookery ${ }^{5}$ (Fig. 4); however, this cannot be confirmed without genetic evidence.

${ }^{5}$ A. Aguayo, pers. comm. 23 November 2018, Instituto Antártico Chileno (INACH), Punta Arenas, Chile. 

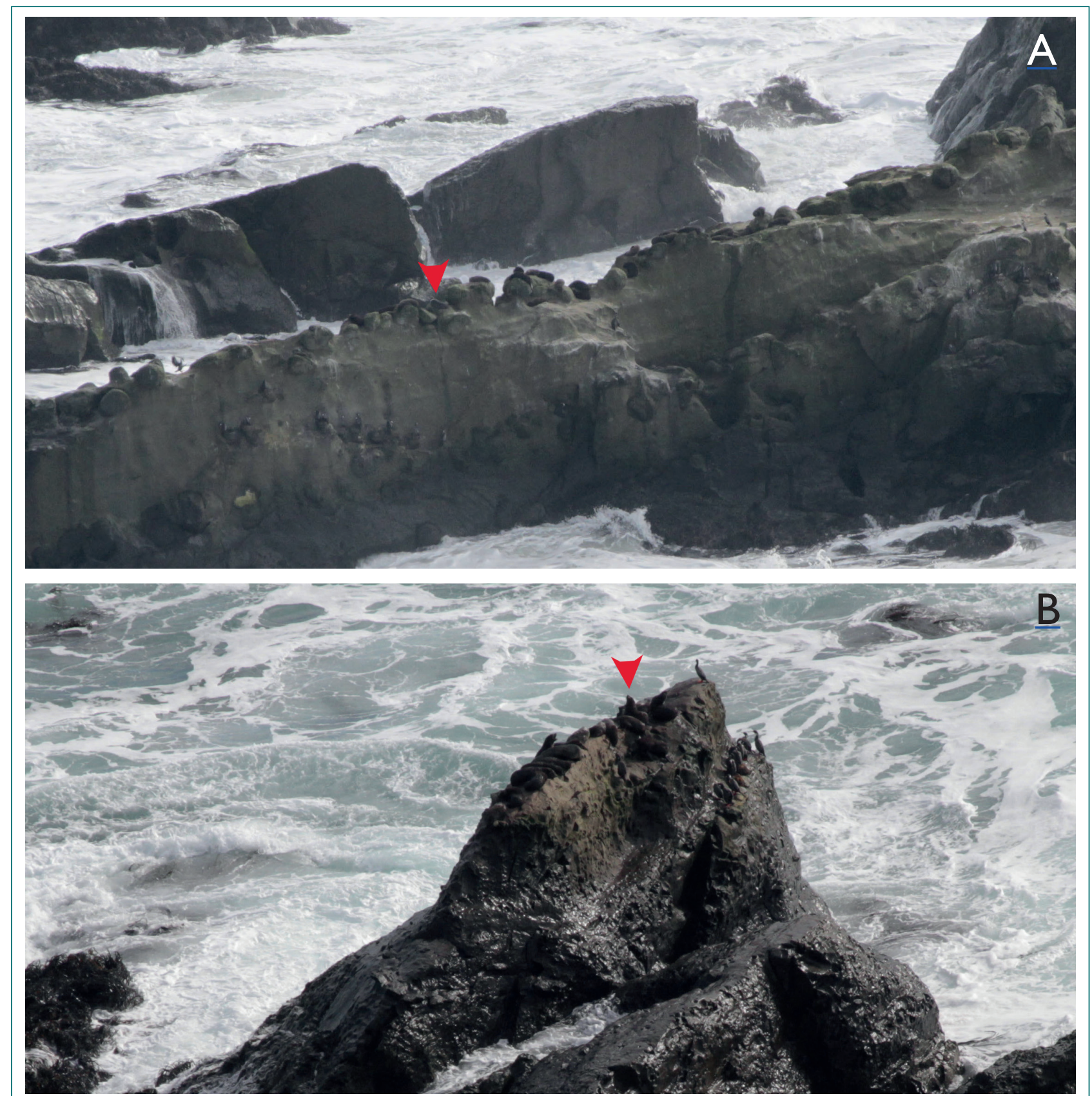

Figure 3. New non-breeding colonies of the South American fur seal (Arctocephalus australis) in central Chile (a) Islote del Trabajo (38 $25^{\prime}$ 'S) and (b) Islote Quechol (38 $26^{\prime}$ 'S). Both colony sightings were performed on 01July 2015 between 12:00 and 13:00 (austral winter). Arrowheads indicate females. Photo credit: L. René Durán.

From SERNAPESCA records, a total of 10 SAFS were registered in ten haul-out sites. Among the fur seals sighted only two were registered in the Chiloé Archipelago, at Pupelde (41 $53^{\circ} S$ ) and Quellón ( $\left.43^{\circ} 07^{\prime} S\right)$; whereas the other eight fur seals were found in mainland coast haul-out sites (Fig. 2).

In summary, we registered a total of 54 SAFS along the Chilean distribution gap. Most of the SAFS were recorded during the austral winter $(n=48 ; 89 \%)$ with lower proportions in the summer $(n=4 ; 7 \%)$, spring $(n=1 ; 2 \%)$ and autumn $(\mathrm{n}=1 ; 2 \%)$ seasons. The individuals were categorized as adult males $(n=5 ; 9 \%)$, adult females $(n=$
39; 72\%), juveniles $(n=4 ; 8 \%)$ and indeterminates $(n=6$; $11 \%$ ) (Fig. 2). The other fur seals sighted in haul-out sites appeared solitary; all of them were resting and returned alone or by rescue action (performed by SERNAPESCA Officials) to the marine environment (Table 1).

The distribution of SAFS in their northern range in Chile was reported for first time in 1982 in the Antofagasta Region $\left(23^{\circ} 35^{\prime} \mathrm{S}\right)$ and subsequently corroborated by the sightings of a number of individuals in Punta Comache $\left(21^{\circ} 11^{\prime} S\right)$ in the same year and 20 individuals in Punta Patache (20 $51^{\prime}$ 'S) in 1984, likely as result of dispersal activity from colonies in 


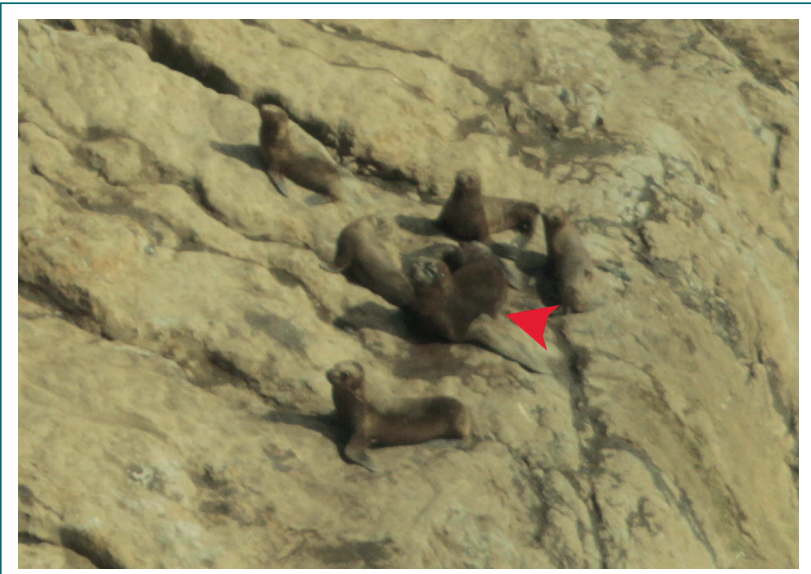

Figure 4. Sighting of an indeterminate sea lion (probably a hybrid specimen between a South American fur seal, Arctocephalus australis, and a South American sea lion, Otaria byronia), in Punta Chaiguaco haul-out site during the austral summer of 2016. The individual appeared between a group of five juvenile females of South American sea lions. Arrowhead indicates the purportedly hybrid specimen. Photo credit: L. René Durán.

southern Peru (Torres, 1985). Later, a synoptic census in the same geographic area during the summer of 1996 registered 20 haul-out sites (comprising 1,598 individuals), with Punta Pichalo (19³1'S) being the only breeding colony (with 38 pups), suggesting that the population was in a process of gradual colonization towards the south ${ }^{6}$. Nowadays, the northern population of SAFS showed an increase in the number of breeding colonies $(n=3)$ and total number of SAFS (5,378 individuals) in the last census carried out during the summer of 2007. Among these, Punta Pichalo (19 $31^{\prime} S$ ) and Punta Campamento (2304'S) stand out as the largest breeding grounds of SAFS in northern Chile (76 and 210 pups registered, respectively) ${ }^{2,7}$.

The high rates of mortality and the dispersion of individuals towards the south before the 1982-1983 ENSO climatological event have contributed to the presence and increased numbers of SAFS in northern Chile, making this species a possible biological indicator (Torres, 1985). However, the strong 1997-1998 ENSO caused a considerable decline in the Peruvian population of SAFS (72\%), mostly because of starvation due to low availability of anchovies in Peru and a subsequent migration of individuals to the south searching for food ${ }^{8}$ (Stevens and Boness, 2003).

${ }^{6}$ Sielfeld, W., Amado, N., Peredo, R., Vargas, M., Guerra, C., Malinarich, A., Acuña, E., Cerda, G., Bolvarán, A., Durán, L.R., Aguayo, A., Sepúlveda, M., Palma, F., Veloso, X., Guerra, Y., Grau, R. and Galáz, J.L. (1997) Monitoreo de la pesquería y censo del lobo marino común en el litoral de la I-IV Regiones. Proyecto Fondo de Investigación Pesquera FIP 95-28.

${ }^{7}$ Bartheld, J., Pavés, H., Contreras, F., Vera, C., Manque, C., Miranda, D., Sepúlveda, D., Artacho, P. and Ossman, L. (2008) Cuantificación poblacional de lobos marinos en el litoral de la I a VI Región. Informe Final Proyecto FIP N²006-50.
The increase in population, natality and number of breeding colonies suggest population growth in southern Chile. Sielfeld et al. (1977) considered the population status of SAFS in the Magallanes Region in at least 88,200 individuals. Summer censuses performed in the Los Lagos and Aysén regions showed a population increase from 2,828 (two breeding colonies) in 1998 to 5,524 (four breeding colonies) individuals in 2007, finally reaching a total of 9,595 individuals (six breeding colonies) in 2012,10,11.

The SAFS population growth and range extension in central Chile documented here is likely to be the result of a combination of factors, such as ENSO events promoting dispersal from affected areas, the recovery process at population level after cessation of sealing, and favorable physical environmental conditions, all of which could be propitiating an extension of their range and consequently filling the gap in their distribution in central Chile. A similar situation is likely occurring in the Atlantic Ocean, where the occurrence of SAFS in the Argentinian Patagonia has been historically registered in Islote Lobos $\left(41^{\circ} 24^{\prime} S\right)$ and the recent presence of SAFS has been reported in San Matías Gulf (Svendsen et al., 2013). This also indicates an analogous situation on the Pacific coast, which is currently facing imminent population growth and the presence of a natural corridor between distant SAFS colonies established in northern and southern Chile.

The possible hybrid individual reported in Punta Chaiguaco rookery matches with the adult hybrid female described by Franco-Trecu et al. (2016) in Lobos Island (Uruguay). This in turn suggests that SAFS and SASL in southern Chile are sharing habitat and colonies within the distribution gap, promoting the hybridization among species.

It is important to emphasize that the presence of SAFS

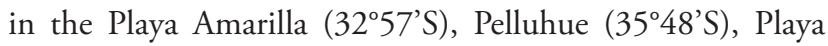
Ramuncho ( $36^{\circ} 45^{\prime} S$ ) and Punta Chaiguaco (42 $59^{\prime} \mathrm{S}$ ) haulout sites (Table 1) in summer raises the possibility that subadults disperse to feed after the breeding season from nearby colonies (Szteren, 2015). The presence of SAFS has been previously reported in the Chiloé Archipelago: Playa Pumillahue ( $41^{\circ} 56^{\prime}$ S) and Metalqui Island (42 $11^{\prime}$ 'S). Among these, the case of Metalqui Island stands out, where in 1977 SAFS females and pups were sighted, presenting exceptionally

${ }^{8}$ Arias-Schreiber, M. and Rivas, C. (1998) Distribución, tamaño y estructura de las poblaciones de lobos marinos (Arctocephalus australis y Otaria byronia) en el litoral Peruano, en noviembre 1996 y marzo 1997. Informe Progresivo del Instituto del Mar del Perú, Callao, Perú.

${ }^{9}$ Oporto, J., Brieva, L., Navarro, R. and Turner, A. (1999) Cuantificación poblacional de lobos marinos en la X y XI Regiones. Informe Final Proyecto FIP 97-44.

${ }^{10}$ Oliva, D., Sielfeld, W., Sepúlveda, M., Pérez, M.J., Moraga, R., Urra, A., Schrader, D., Pavés, H. and Buscaglia, M. (2008) Plan de acción para disminuir y mitigar los efectos de las interacciones del lobo marino común (Otaria flavescens) con las actividades de pesca y acuicultura. Informe final Proyecto FIP 2006-34.

${ }^{11}$ Oliva, D., Sepúlveda, M., Durán, L.R., Urra, A., Sielfeld, W., Moraga, R., Pavés, G. and Muñoz, L. (2012) Cuantificación poblacional de lobos marinos en las Regiones X-XI y propuesta de escenarios de manejo. Informe Final Proyecto FAP ID 4728-46-LP11. 
Table 1. Summary of sightings of South American fur seal (Arctocephalus australis) along the southeast Pacific coast of Chile, SAFS gap of distribution (29 02'S - 4336' S), from 2009 to 2018 per haul-out sites and non-breeding colonies. Age classes: $\mathrm{M}=$ Adult Males, $\mathrm{F}=$ Adult Females, J= Juveniles, I= Indeterminate). Locations arranged from north to south.

\begin{tabular}{|c|c|c|c|c|}
\hline Location & Habitat & Season & Fur seals sighted & $\begin{array}{c}\text { GPS } \\
\text { coordinates }\end{array}$ \\
\hline Caleta San Pedro & Sandy beach & Winter & $1(\mathrm{~F})$ & $29^{\circ} 52^{\prime} \mathrm{S} ; 71^{\circ} 16^{\prime} \mathrm{W}$ \\
\hline Playa Amarilla & Rocky & Summer & $1(\mathrm{I})$ & $32^{\circ} 57^{\prime} \mathrm{S} ; 71^{\circ} 32^{\prime} \mathrm{W}$ \\
\hline Duao & Rocky & Spring & $1(\mathrm{~F})$ & $34^{\circ} 53^{\prime} \mathrm{S} ; 72^{\circ} 10^{\prime} \mathrm{W}$ \\
\hline Pelluhue & Sandy beach & Summer & $1(\mathrm{I})$ & $35^{\circ} 48^{\prime} \mathrm{S} ; 72^{\circ} 34^{\prime} \mathrm{W}$ \\
\hline Playa Ramuncho & Sandy beach & Summer & $1(\mathrm{I})$ & $36^{\circ} 45^{\prime} \mathrm{S} ; 73^{\circ} 11^{\prime} \mathrm{W}$ \\
\hline San Vicente & Sandy beach & Autumn & $1(\mathrm{I})$ & $36^{\circ} 56^{\prime} \mathrm{S} ; 73^{\circ} 09^{\prime} \mathrm{W}$ \\
\hline Playa Larga de Lebu & Sandy beach & Winter & $1(\mathrm{I})$ & $37^{\circ} 43^{\prime} \mathrm{S} ; 73^{\circ} 39^{\prime} \mathrm{W}$ \\
\hline Islote del Trabajo & Rocky islet & Winter & $27(\mathrm{M}=2, \mathrm{~F}=23, \mathrm{~J}=2)$ & $38^{\circ} 25^{\prime} \mathrm{S} ; 73^{\circ} 56^{\prime} \mathrm{W}$ \\
\hline Islote Quechol & Rocky islet & Winter & $16(\mathrm{M}=3, \mathrm{~F}=13)$ & $38^{\circ} 26^{\prime} \mathrm{S} ; 73^{\circ} 54^{\prime} \mathrm{W}$ \\
\hline Pelluco & Sandy beach & Winter & $1(\mathrm{~J})$ & $41^{\circ} 29^{\prime \prime S} ; 72^{\circ} 54^{\prime \prime W}$ \\
\hline Pupelde & Wetland & Winter & $1(\mathrm{~F})$ & $41^{\circ} 53^{\prime} \mathrm{S} ; 73^{\circ} 46^{\prime} \mathrm{W}$ \\
\hline Punta Chaiguaco & Rocky & Summer & $1\left(I^{*}\right)$ & $42^{\circ} 59^{\prime \prime} \mathrm{S} ; 74^{\circ} 15^{\prime} \mathrm{W}$ \\
\hline Quellón & Sandy beach & Winter & $1(\mathrm{~J})$ & $43^{\circ} 07^{\prime} \mathrm{S} ; 73^{\circ} 37^{\prime} \mathrm{W}$ \\
\hline
\end{tabular}

* Possible hybrid individual between a SASL (South American sea lion) and a SAFS (South American fur seal).

different characteristics from those of SASL, such as greyishbrown fur, thin head and body and protruding ears clearly visible (Saavedra, 1980). The fact that from 1977 to the present SAFS individuals (even pups) have been recorded frequently in the geographical area means that the species previously inhabited the archipelago successfully, which could now be leading to a recolonization process from Guafo Island, the largest breeding colony of the species in southern Chile (Paves and Schlatter, 2008).

During the winter season, $89 \%$ of individuals (only adult male and female) arrive at the gap area. Szteren (2015) recorded an abundance of SASL and SAFS in poorly known sites along the Uruguayan coast. Interestingly, at Las Pipas non-breeding colony, subadult males, females and juveniles were the predominant age classes of SAFS. The maximum abundance was found in winter, declining in number abruptly during spring and remaining very low in summer, suggesting that animals may be migrating from breeding areas to these locations, probably to use them as resting grounds near feeding areas. Our results suggest the dispersion of mature individuals during the foraging season to Chilean middle latitudes. The SAFS sightings inside the gap of distribution showed a preference for rocky islets (Fig. 3; Table 1), such as the case of Islote del Trabajo and Islote Quechol (both adjacent to Mocha Island), to establish colonies during the austral winter (post-reproductive season). These rocky islets present the topographic characteristics previously described for SAFS colonies (Stevens and Boness, 2003). Forty-three individuals congregated these two islets combined, which may be considered as a composed non-breeding colony (since these are located at a distance of less than a mile), fulfilling the assumption stipulated by Grandi et al. (2008) for a nonbreeding colony.

The Pleistocene glaciations could have played a deterministic role in the living conditions of SAFS. The genealogical relationship between haplotypes revealed a pattern of phylogeographic structure with two main haplogroups corresponding to the main breeding areas of the SAFS (Peru and Uruguay). Significant genetic differences have been determined from these results, which suggest a long period of isolation between the Pacific and Atlantic populations, which in turn could have shaped the current SAFS distribution and the reproductive colonies in the Chilean territory (Túnez et al., 2013).

The establishment of new non-breeding colonies and haulout sites in central Chile would not be a surprise and could foster new breeding colonies inside the gap of distribution in the future. It is likely that the current abundance status of the SAFS is a result of the heavy sealing activity carried out during the end of the eighteenth and the first half of the nineteenth centuries (Martinic, 1987), when the capture reached more than 800,000 furs (Bonner, 1982) ${ }^{2}$ and Guafo Island was one of the sealing locations (Mayorga, 2017). Today, we believe that SAFS are reaching Mocha Island in central Chile as a resting or feeding ground, a location that the species used to inhabit in the past (Sielfeld et al., 1977; Torres et al., 2000) and which could have been the northern limit of the South Pacific population of SAFS.

Here we present the first observations during the last decade of solitary individuals and aerial graphic records of 
two non-breeding colonies inside the gap of distribution in central Chile. Although Repenning et al. (1971) described an erroneous continuous distribution of SAFS in Chile, our study shows that currently this pattern could be getting closer to becoming real. Also, current data suggest that the Guafo Island population belongs to the same lineage and has radiated from the Atlantic population, presenting an amphi-oceanic distribution (Rodrigues et al., 2018). This in turn suggests that the Mocha Island individuals arrive from Guafo Island due to the historical sealing background and are recolonizing the area. However, the Peruvian/northern Chile population will probably continue to be reproductively isolated (Oliveira and Brownell, 2014). Therefore, it is important to continue monitoring this area with standard effort throughout the entire year, and to continue surveying the Magallanes Region; to assess the population trend within the gap of distribution and the southern population abundance of SAFS, and to define the best strategies to ensure its correct conservation and future research of its ecology.

\section{Acknowledgments}

This study was supported by Fondo de Investigación Pesquera y de Acuicultura (Project FIP 2014-29) and Dirección de Investigación Universidad de Valparaíso (Project DIUV 38/2013). We acknowledge SIAC-SERNAPESCA for providing the stranding data. We are also grateful to Anelio Aguayo for helping with the identification of Punta Chaiguaco purportedly hybrid specimen, Sara Meinecke for English revision, and three anonymous reviewers for their corrections and valuable suggestions on this manuscript. Special thanks to Alicia Guerrero who provided helpful comments on the last version of the manuscript. GP acknowledges CONICYTPCHA/Doctorado Nacional/2016-21161109 PhD scholarship.

\section{References}

Aguayo, A. and Maturana, R. (1973) Presencia del lobo marino común (Otaria flavescens) en el litoral chileno. Biología Pesquera 6: 45-75.

Bininda-Emonds, O.R.P. and Gittleman, J.L. (2000) Are pinnipeds functionally different from fissiped carnivores? The importance of phylogenetic comparative analyses. Evolution 54(3):1011-1023.

https://doi.org/10.1111/j.0014-3820.2000.tb00100.x

Bonner, W.N. (1982) Seals and man. A study of interactions. University of Washington Press, Seattle, WA. 170 pp.

Cárdenas-Alayza, S. (2012) Prey abundance and population dynamics of South American fur seals (Arctocephalus australis) in Peru. MSc. Thesis. University of British Columbia, Vancouver, Canada. 69 pp.
Cárdenas-Alayza, S., Oliveira, L. and Crespo, E. (2016) Arctocephalus australis. The IUCN Red List of Threatened Species 2016: e.T2055A45223529.

http://dx.doi.org/10.2305/IUCN.UK.2016-1.RLTS. T2055A45223529.en

Collins, M., An, S.I., Cai, W., Ganachaud, A., Guilyardi, E., Jin, F.F., Jochum, M., Lengaigne, M., Power, S., Timmermann, A., Vecchi, G. and Wittenberg, A. (2010) The impact of global warming on the tropical Pacific Ocean and El Niño. Nature Geoscience 3(6): 391. https://doi.org/10.1038/ngeo868

Crespo, E.A., Schiavini, A.C.M., García, N.A., FrancoTrecu, V., Goodall, R.N.P., Rodríguez, D., Morgante J.S. and Oliveira, L.R. (2015) Status, population trend and genetic structure of South American fur seals, Arctocephalus australis, in southwestern Atlantic waters. Marine Mammal Science 31(3): 866-890. https://doi.org/10.1111/mms.12199

Franco-Trecu, V. (2015) Tácticas comportamentales de forrajeo y apareamiento y dinámica poblacional de dos especies de otáridos simpátricas con tendencias poblacionales contrastantes. Ph.D. Thesis. Universidad de la República, Montevideo, Uruguay. 225 pp.

Franco-Trecu, V., Costa, P., Schramm, Y., Tassino, B. and Inchausti, P. (2014) Sex on the rocks: reproductive tactics and breeding success of South American fur seal males. Behavioral Ecology 25(6): 1513-1523.

https://doi.org/10.1093/beheco/aru145

Franco-Trecu, V., Abud, C., Feijoo, M., Kloetzer, G., Casacuberta, M. and Costa-Urrutia, P. (2016) Sex beyond species: the first genetically analyzed case of intergeneric fertile hybridization in pinnipeds. Evolution \& Development 18(2): 127-136. https://doi.org/10.1111/ede.12183

Franco-Trecu, V., Drago, M., Grandi, M.F., Soutullo, A., Crespo, E.A. and Inchausti, P. (2019) Abundance and population trends of the South American fur seal (Arctocephalus australis) in Uruguay. Aquatic Mammals 45(1): 48-55.

https://doi.org/10.1578/AM.45.1.2019.48

Grandi, M.F., Dans, S.L. and Crespo, E.A. (2008) Social composition and spatial distribution of colonies in an expanding population of South American sea lions. Journal of Mammalogy 89(5): 1218-1228.

https://doi.org/10.1644/08-MAMM-A-088.1

Lindenfors, P., Tullberg, B.S. and Biuw, M. (2002) Phylogenetic analyses of sexual selection and sexual size dimorphism in pinnipeds. Behavioral Ecology and Sociobiology 52(3): 188-193.

https://doi.org/10.1007/s00265-002-0507-x

Majluf, P. (1987) Reproductive ecology of females South American fur seals at Punta San Juan, Peru. Ph.D. Thesis. University of Cambridge, Cambridge. 126 pp. 
Martinic, M. (1987) Navegantes norteamericanos en aguas de Magallanes durante la primera mitad del siglo XIX. Anales del Instituto de la Patagonia 17: 11-17.

Mayorga, M. (2016) Antecedentes históricos referidos a la caza de lobos marinos y su interacción con el medio geográfico y humano en el extremo austral americano: El caso del lobero escocés William Low. Magallania 44(2): 37-64.

https://doi.org/10.4067/S0718-22442016000200002

Mayorga, M. (2017) Actividad lobera temprana en la Patagonia oriental: caza de mamíferos marinos. RIVAR 4(11): 31-51.

NCDC-NOOA. (2004) The top 10 El Niño Events of the 20th Century. Available at http://www.ncdc.noaa.gov/oal climate/research/1998/enso/10elnino.html. Downloaded 25 November 2018.

Oliveira, L.R. (2013) Carnívoros marinos. Pages 405-427 in Weber, M.M., Roman, C. and Cáceres, N.C. (eds) Mamíferos do Rio Grande do Sul, Santa Maria, Editora UFMS.

Oliveira, L.R. and Brownell, R.L. (2014) Taxonomic status of two subspecies of South American fur seals: Arctocephalus australis australis vs. A. a. gracilis. Marine Mammal Science 30(3): 1258-1263. https://doi.org/10.1111/mms.12098

Oliveira, L.R., Arias-Schreiber, M., Meyer, D. and Morgante, J.S. (2006) Effective population size in a bottlenecked fur seal population. Biological Conservation 131(4): 505-509.

https://doi.org/10.1016/j.biocon.2006.02.017

Oliveira, L.R., Hoffman, J.I., Hingst-Zaher, E., Majluf, P., Muelbert, M.M.C., Morgante, J.S. and Amos, W. (2008) Morphological and genetic evidence for two evolutionarily significant units (ESUs) in the South American fur seal, Arctocephalus australis. Conservation Genetics 9(6): 14511466. https://doi.org/10.1007/s10592-007-9473-1

Oliveira, L.R., Meyer, D., Hoffman, J., Majluf, P. and Morgante, J.S. (2009) Evidence of a genetic bottleneck in an El Niño affected population of South American fur seals, Arctocephalus australis. Journal of the Marine Biological Association of the United Kingdom 89(8): 1717-1725. https://doi.org/10.1017/S0025315409000162

Pavés, H. and Schlatter, R. (2008) Breeding season of the southern fur seal, Arctocephalus australis, at Guafo Island, southern Chile. Revista Chilena de Historia Natural 81(1): 137-149.

http://dx.doi.org/10.4067/S0716-078X2008000100011

Pavés, H., Schlatter, R., Franco-Trecu, V., Páez, F., Sielfeld, W., Araos, V., Giesecke, R., Batallé, L.M. and Cappozzo, L.H. (2016) Breeding season of the South American fur seal (Arctocephalus australis, Otariidae: Carnivora): New data for establishing independent evolutionary histories? Revista de Biología Marina y Oceanografía 51(2): 241-253.

https://doi.org/10.4067/S0718-19572016000200003
Repenning, C.A., Peterson, R.S. and Hubbs, C.L. (1971) Contributions to the systematics of the southern fur seals, with particular reference to the Juan Fernandez and Guadalupe species. Antarctic Pinnipedia 18: 1-34.

https://doi.org/10.1029/AR018p0001

Rodrigues, P., Seguel, M., Gutiérrez, J., Pavés, H. and Verdugo, C. (2018). Genetic connectivity of the South American fur seal (Arctocephalus australis) across Atlantic and Pacific oceans revealed by mitochondrial genes. Aquatic Conservation: Marine and Freshwater Ecosystems 28(2): 315323. https://doi.org/10.1002/aqc. 2870

Saavedra, R. (1980) Isla Metalqui, una lobería que necesita protección. Medio Ambiente 4(2): 35-40.

Sepúlveda, M., Oliva, D.P. and Palma, F.J. (2001) Daily and annual circarhythms activity in the South American sea lion Otaria flavescens (Carnivora: Otariidae) at the central zone of Chile. Revista de Biología marina y Oceanografía 36(2): 181187. https://doi.org/10.4067/S0718-19572001000200006

Sepúlveda, M., Oliva, D., Urra, A., Pérez-Álvarez, M.J., Moraga, R., Schrader, D., Inostroza, P., Melo, A., Díaz, H. and Sielfeld, W. (2011) Distribution and abundance of the South American sea lion Otaria flavescens (Carnivora: Otariidae) along the central coast off Chile. Revista Chilena de Historia Natural 84: 97-106.

https://doi.org/10.4067/S0716-078X2011000100007

Sielfeld, W., Venegas, C. and Atalah, A. (1977) Consideraciones acerca del estado de los mamíferos marinos en Chile. Anales del Instituto de la Patagonia 8: 297-312.

Sielfeld W. (1999) Estado del conocimiento sobre conservación y preservación de Otaria flavescens (Shaw, 1800) y Arctocephalus australis (Zimmermann, 1783) en las costas de Chile. Estudios Oceanológicos 18: 81-96.

Simmonds, M.P. and Isaac, S.J. (2007) The impacts of climate change on marine mammals: early signs of significant problems. Oryx 41(1): 19-26.

https://doi.org/10.1017/S0030605307001524

Stevens, M.A. and Boness, D.J. (2003) Influences of habitat features and human disturbance on use of breeding sites by a declining population of southern fur seals (Arctocephalus australis). Journal of Zoology 260(2): 145-152.

https://doi.org/10.1017/S0952836903003583

Strange, I.J. (1992) A field guide to the wildlife of the Falkland Islands and South Georgia. Harper \& Collins, London, U.K. 188 pp.

Svendsen, G., Dans, S.L., González, R.A.C., Romero, M.A. and Crespo, E.A. (2013) Occurrence of South American fur seals Arctocephalus australis (Zimmermann, 1783) in San Matías Gulf, Patagonia, Argentina. Latin American Journal of Aquatic Research 41(3): 576-583.

https://doi.org/103856/vol41-issue3-fulltext-19 
Szteren, D. (2015) Otaria flavescens and Arctocephalus australis abundance in poorly known sites: a spatial expansion of colonies? Brazilian Journal of Oceanography 63(3): 337-346. http://dx.doi.org/10.1590/S1679-87592015090606303

Torres, D. (1985) Presencia del lobo fino sudamericano (Arctocephalus australis) en el norte de Chile, como consecuencia de El Niño 1982/83. Investigaciones Pesqueras 32: 225-233.

Torres, D., Aguayo-Lobo, A. and Acevedo, J. (2000) Mamíferos Marinos de Chile. II. Carnivora. Serie Cientifica INACH 50: 25-103.
Túnez, J.I., Cappozzo, H.L., Pavés, H., Albareda, D A. and Cassini, M.H. (2013) The role of Pleistocene glaciations in shaping the genetic structure of South American fur seals (Arctocephalus australis). New Zealand Journal of Marine and Freshwater Research 47(2):139-152.

https://doi.org/10.1080/00288330.2012.753463

Zimmermann, E.A.W. (1783) Geographische Geschichte des Menschen, und der allgemein verbreiteten vierfussigen Thiere. Leipzig, Germany. 